\title{
PENGUATAN KAPASITAS TATA KELOLA KEUANGAN DAN PRODUKSI BAGI KELOMPOK MASYARAKAT PENGRAJIN KARAWO DESA WISATA RELIGIUS BONGO KABUPATEN GORONTALO
}

\author{
Ismet Sulila \\ Program Studi Administrasi Publik, Fakultas Ekonomi, Universitas Negeri Gorontalo, Gorontalo, Indonesia \\ *Penulis Korespondensi: ismet.sulila@gmail.com
}

\begin{abstract}
Abstrak
Sektor ril telah terbukti mampu memberikan kontribusi penting dalam pembangunan ekonomi di daerah. Kabupaten Gorontalo memiliki beberapa kelompok binaan usaha mikro kecil sulaman kain karawo, yang diantaranya berlokasi di desa wisata religius Bongo. Peran perguruan tinggi yang dilaksanakan melalui pengabdian masyarakat difokuskan pada upaya konkrit secara bertahap dan terukur dalam meningkatkan Pemberdayaan Masyarakat. Kegiatan ini dilaksanakan pada kelompok sasaran pengrajin sulaman kain karawo untuk menciptakan keunggulan produk karawo yang memenuhi Standard Mutu Pasar Moderen di tingkat lokal, nasional dan internasional. Adapun tema kegiatan pengabdian adalah penguatan kapasitas tata kelola keuangan, bahan baku, proses dan produksi bagi kelompok masyarakat pengrajin karawo Desa Wisata Religius Bongo. Berdasarkan hasil implementasi kegiatan pada khalayak sasaran maka diperoleh hasil sebagai berikut : 1) terdapat peningkatan pemahaman terhadap teori dan kemampuan dalam praktek tata kelola keuangan oleh kelompok sasaran. 2) meningkatnya kemampuan dalam pemenuhan bahan baku berdasarkan kebutuhan produksi. 3) terstandarisasinya proses produksi ragam produk karawo. 4) terpenuhinya kebutuhan ragam produk kain karawo sesuai dengan kebutuhan pasar. Pada dasarnya secara keseluruhan rangkaian kegiatan pengabdian masyarakat telah memberikan pengalaman empirik dan manfaat baik bagi kelompok masyarakat sebagai sasaran, tim dosen pelaksana, perguruan tinggi dan pemerintah setempat.
\end{abstract}

Kata kunci: Penguatan Financial, Bahan Baku, Produksi, Proses

\begin{abstract}
The real sector has evidently been able to provide an important contribution to regional economic development. Gorontalo regency has a number of small and micro enterprise groups of Karawo artisans participating in a development program; some of the groups are based in religious tourism village Bongo. This activity targets the group of Karawo artisans to promote quality Karawo products that meet the local, national, and international standard of modern market quality. The theme of the community service revolves around the capacity reinforcement of financial, raw materials, process, and production management for the Karawo artisan enterprises in religious tourism Bongovillage. The resultsreveal that: 1) there is an improvement in the insight regarding the theory and the ability in the practice of financial management of the target groups, 2) there is an improvement regarding the capability of thefulfilment of raw materials based on the production needs, 3) the productionof Karawo embroidery has been standardized, 4) the fulfilment of the needs of other varieties of Karawo embroidery based on the market needs. Generally, the overall activities of community services have provided the community with empirical experience and advantages for the target community, lecturer team, universities, as well as the local government.
\end{abstract}

Keywords: Reinforcement of Finance, Raw Materials, Process, Production

\section{PENDAHULUAN}

Desa Wisata Religius Bongo merupakan salah satu Desa unggulan yang berbatasan langsung dengan wilayah Kota Gorontalo. Desa Bongo juga merupakan desa pesisir pantai selatan Gorontalo yang dikenal memiliki beragam potensi baik ekonomi, sosial dan budaya. Desa Bongo terbagi dalam 3 Dusun yaitu Dusun barat, timur dan disun tengah. Secara sosial potensi yang dimiliki dini diantaranya perayaan hari besar keagamaan yang dikemas dengan kegiatan kebudayaan lokal. Sedangkan potensi budaya dapat dilihat dari peninggalan sejarah kerajaan yang juga dikemas dengan kegiatan budaya masyarakat lokal. Adapun potensi ekonomi desa ini memiliki potensi diantaranya perikanan, wisata alam, sejarah dan 
kerajinan tangan karawo khas desa wisata religius Bongo. Berdasarkan ragam potensi di atas terdapat salah satu potensi yang menarik untuk terus dikembangkan oleh masyarakat setempat, yaitu usaha kerajinan sulaman tangan kain karawo. Saat ini jumlah pengrajin karawo di desa Bongo mencapai 100 (seratus) orang pengrajin. Jumlah tersebut merupakan jumlah terbesar pengrajin yang berbasis pedesaan. Produk sulaman kain karawo memiliki jenis/ragam produk yang biasanya digunakan dalam berbagai kegiatan masyarakat baik formal maupun non formal, yang dapat dirinci sebagai berikut :

Tabel 1. Ragam Jenis Produk Karawo

\begin{tabular}{|c|l|l|}
\hline No & \multicolumn{1}{|c|}{ Jenis Produk } & \multicolumn{1}{|c|}{$\begin{array}{c}\text { Segmen } \\
\text { Konsumen }\end{array}$} \\
\hline 1 & Karawo Sutra Tapeta & Pria dan Wanita \\
\hline 2 & Karawo kombinasi batik & Pria dan Wanita \\
\hline 3 & Karawo jilbab & Wanita \\
\hline 4 & Karawo tatakan gelas set & Produk Umum \\
\hline 5 & Karawo taplak meja & Produk Umum \\
\hline 6 & Karawo kipas-kipas & Wanita \\
\hline
\end{tabular}

Sumber : Identifikasi Lapangan 2018

Tingginya minat masyarakat untuk terus mengembangkan karawo didorong oleh upaya untuk terus melestarikan produk sulaman kain karawo sebagai warisan leluhur secara turun temurun dari masyarakat pendahulu di Gorontalo. Upaya tersebut ternyata memiliki dampak positif lainya yaitu potensi terhadap pengembangan produk sulaman karawo sebagai kerajinan unggulan khas yang beradal dari desa Bongo Provinsi Gorontalo. Kondisi tersebut juga didukung oleh status desa bongo sebagai desa wisata religius dengan tingkat kunjungan setiap harinya mencapai rata-rata 10 (sepuluh) orang setiap harinya, baik wisatawan lokal maupun wisatawan mancanegara.

Berbagai potensi di atas masih perlu untuk terus dikembangkan dengan berfokus pada berbagai aspek, diantaranya aspek manajemen. Selanjutnya berdasarkan hasil observasi awal di lapangan menunjukkan bahwa kelompok sasaran membutuhkan intervensi dari pihak lain dalam hal pengembangan produk dan tata kelola manajemen. Salah satu intervensi yang diharapkan adalah dari perguruan tinggi dalam bentuk penerapan ilmu pengetahuan dan teknologi sesuai dengan kebutuhan kelompok sasaran. Pada aspek manajemen fokus kegiatan yang dilakukan adalah penguatan tata kelola keuangan, bahan baku, produksi dan produk sulaman kain karawo. Keempat fokkus tersebut secara faktual dapat dijelaskan sebagai berikut : 1) Tata Kelola Keuangan: masyarakat selaku kelompok sasaran belum memahami bagaimana pentingnya penyusunan rencana kebutuhan anggaran, alternatif sumber pembiayaan, alokasi pembiayaan, jangka waktu pembiayaan dan siklus kas. 2) Bahan Baku: kelompok sasaran belum mampu mengidentifikasi kebutuhan bahan baku, jumlah bahan baku sesuai jenis produk karawo dan penetapan standar kualitas bahan baku. 3) Produksi: kelompok sasaran belum mampu mengidentifikasi dan menyusun tahapan produksi untuk berbagai jenis produk karawo, standarisasi produksi karawo dan pemenuhan fasilitas produksi sesuai kebutuhan. 4) Produk: Kelompok sasaran belum mampu mengidentifikasi dan menetapkan standar kualitas ragam produk karawo.

Berdasarkan potensi dan masalah yang dihadapi oleh kelompok sasaran sebagaimana dijelaskan di atas, maka tim pelaksana program pengembangan produk unggulan daerah (PPPUD) tahun 2018 telah melaksanakan observasi dan penyusunan program dengan kelompok sasaran ibu-ibu dan remaja desa Bongo yang juga selaku pengrajin karawo di desa ini untuk mengikuti kegiatan penguatan tata kelola keuangan, bahan baku, proses dan produksi. Oleh karena itu fokus kegiatan intervensi ilmu pengetahuan dan teknologi oleh tim pelaksana PPPUD terhadap kelompok sasaran dirinci sebagai berikut :

1) Penguatan tata kelola keuangan yang meliputi : a) identifikasi kebutuhan pembiayaan, b) penyusunan rencana kerja anggaran, c) identifikasi dan penyusunan sumber penggunaan dana, d) bimbingan teknis tata kelola keuangan.

2) Penguatan bahan baku yang meliputi : a) identifikasi kebutuhan baku untuk setiap jenis produk karawo, b) pembiayaan bahan baku, c) penetapan standar bahan baku sesuai jenis produk, d) kualiti kontrol jenis bahan baku, e) kerjasama suplay bahan baku sesuai kebutuhan.

3) Penguatan aspek Produksi yang meliputi: a) identifikasi aspek produksi, b) standarisasi produksi, c) pemenuhan aspek pendukung produksi, d) quality kontrol produksi, e) kesinambungan produksi.

4) Penguatan aspek produk yang meliputi: a) identifikasi dan penetapan standar qualitas produk, b) penguatan ciri khas produk, c) demo produk, d) klasifikasi produk, e) segmentasi produk.

\section{BAHAN DAN METODE}

Dalam kegiatn ini metode pendekatan yang dilakukan unik dan berbeda yang meliputi : 1) penetapan skala prioritas masalah yang dibenahi dan dibagi pada beberapa tahun, 2) melakukan rekonstruksi dan pembenahan berdasarkan masalah secara bertahap setiap tahun, 3) pembenahan dilakukan berdasarkan pendekatan karakter lokal masyarakat setempat, 4) menyiapkan metode dan teknologi sesuai dengan prioritas masalah dan target yang ditetapkan. Langkah-langkah dalam bentuk program yang akan telah dilaksanakan untuk masing-masing fokus kegiatan dijelaskan sebagai berikut: 1) Tata kelola keuangan yang meliputi: a) identifikasi kebutuhan pembiayaan. Untuk mencapai target yang telahditetapkan maka metode yang digunakan adalah melakukan diskusi dengan kelompok sasaran untuk mengetahui dan menetapkan pembiayaan apasaja yang dibutuhkan dalam pengelolaan usaha. b) penyusunan rencana kerja anggaran. Metode yang digunakan 
adalah diskusi, teori dan praktek mengenai penyusunan rencana kerja keuangan yang efektif. Disamping itu pula diberikan contoh kasus dan solusi pemecahan masalah. c) identifikasi dan penyusunan sumber penggunaan dana. Metode yang digunakan adalah diskusi kelompok, teori dan praktek sumber penggunaan dana baik dari internal kelompok maupun eksternal kelompok yang bersumber dari lembaga keuangan bank dan non bank. d) bimbingan teknis tata kelola keuangan. Metode yang digunakan adalah teori dan praktek tata kelola keuangan sederhana dan siklus kas. 2) Bahan baku: a) identifikasi kebutuhan baku untuk setiap jenis produk karawo. Metode yang digunakan adalah diskusi, teori dan praktek identifikasi dan pemenuhan bahan baku. b) pembiayaan bahan baku. Metode yang digunakan adalah diskusi, teori dan praktek penyusunan sumber pembiayaan bahan baku dan efisiensi. c) penetapan standar bahan baku sesuai jenis produk. Metode yang digunakan adalah diskusi, teori dan praktek penetapan standar ragam jenis produk karawo, d) kualiti kontrol jenis bahan baku. Metode yang digunakan adalah diskusi, teori dan praktek terhadap quality kontrol terhadap bahan baku dan penggunaannya pada ragam jenis produk karawo, e) kerjasama suplay bahan baku sesuai kebutuhan. Metode yang digunakan adalah diskus, teori dan praktek penerapan qualitas kontrol bahan baku. 3) Produksi: yang meliputi: a) identifikasi aspek produksi. Metode yang digunakan adalah diskusi, teori dan praktek mengidentifikasi berbagai aspek produksi yang dibutuhkan kelompok sasaran, b) standarisasi produksi. Metode yang digunakan adalah diskusi, teori dan praktek penetapan standarisasi ragam produk karawo. c) pemenuhan aspek pendukung produksi. Metode yang digunakan adalah diskusi, teori dan praktek pemenuhan aspek pendukung secara bersama-sama dengan mitra terkait, d) quality kontrol produksi. Metode yang digunakan adalah diskusi, teori dan praktek kontrol ragam produksi karawo, e) kesinambungan produksi. Metode yang digunakan adalah diskusi, teori dan praktek berbagai upaya pencapaian target dan upaya jaminan kesinambungan produksi. 4) Produk: yang meliputi: a) identifikasi dan penetapan standar qualitas produk. Metode yang digunakan adalah diskusi, teori dan praktek penetapan standar qualitas ragam produk karawo. b) penguatan ciri khas produk. Metode yang digunakan adalah diskusi, teori dan praktek pengautan ciri khas ragam produk karawo. c) demo produk. Metode yang digunakan adalah diskusi, teori dan praktek demo ragam produk karawo. d) klasifikasi produk. Metode yang digunakan adalah diskusi teori dan praktek klasifikasi ragam produk karawo. e) segmentasi produk. Metode yang digunakan : diskusi, teori dan praktek segmentasi produk karawo untuk memenuhi pasar lokal, nasional dan internasional.

Sementara itu untuk menjamin keberlangsungan dan kebermanfaatan program ini pada masa yang akan datang maka dibutuhkan upaya serius untuk keberlanjutan program. Keberlanjutan program akan ditentukan oleh komitmen kerja kelompok sasaran, pemerintah desa dan tim pelaksana yang bekerjasama dengan karang taruna setempat sebagai pendamping keberlanjutan program. Keterlibatan berbagai pihak terkait pada program kegiatan adalah dalam rangka memetakan potensi dan masalah baru yang mungkin muncul serta solusi konkrit dan alternatifnya. Bantuan teknologi tata kelola keuangan, penanganan bahan baku, produksi dan kualitas produk ragam jenis karawo merupakan upaya meningkatkan efisiensi dan efektifitas pengelolaan usaha karawo. Keberadaan bantuan ini akan meningkatkan kinerja produksi dan pengolahan serta standarisasi mutu karawo yang dilakukan oleh kelompok sasaran. Adapun proses pemasaran dibantu oleh mitra yang meliputi beberapa outlet penjualan yang tersebar di wilayah Kota Gorontalo dan juga pemasaran melalui media sosial.

Adapun alur pelaksanaan program di lapangan digambarkan sebagai berikut :

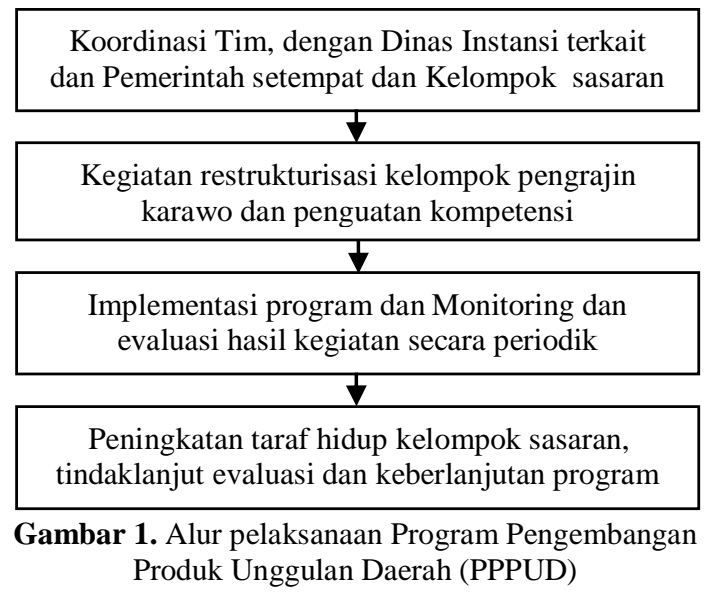

\section{HASIL DAN PEMBAHASAN}

Berdasarkan implementasi program pengembangan produk unggulan daerah (PPPUD) tahun 2018 di lapangan maka hasil dan pembahasannya diuraikan sebagai berikut: 1) Pendampingan program tahap pertama telah dilakukan selama kurang lebih tiga bulan yang telah memberikan dampak pada meningkatnya pemahaman kelompok sasaran dalam fokus penguatan kapasitas tata kelola keuangan. 2) Meningkatnya kemampuan kelompok sasaran dalam fokus penerapan metode penyiapan bahan baku untuk menjamin kontinuitas produksi. 3) Meningkatnya keterampilan kelompok sasaran dalam fokus penerapan teknologi produksi ragam produk karawo untuk menghasilkan kuantitas dan kualitas produk sesuai standar kebutuhan pasar. 4) Bertambahnya pemahaman dan pengetahuan kelompok pengrajin dalam memenuhi standar produksi ragam jenis produk karawo sebagai produk unggulan khas desa wisata religius Bongo. 5) Meningkatnya pemahaman dan kemampuan praktek kelompok sasaran dalam standarisasi produksi. 6) Bertambahnya jumlah kapasitas produksi ragam produk karawo sebagai akibat dari perbaikan manajemen kelompok secara bertahap dan terukur. 7) Bagi mahasiswa memperoleh pengalaman empirik di lapangan tentang berbagai masalah mendasar yang dihadapi masyarakat 
sekaligus berupaya membuat analisis dan solusi konkrit dalam pemecahan masalah secara bertahap dan terukur. 8) Bagi pemerintah setempat dapat memberdayakan masyarakat kelompok pengrajin sulaman kain karawo, meningkatkan produktivitas kelompok, sedikitnya mengurangi tingkat pengangguran dan menggerakkan ekonomi masyarakat setempat. 9) Bagi perguruan tinggi merupakan bentuk kepedulian pada lingkungan masyarakat melalui program pengabdian masyarakat sebagai bentuk penerapan ilmu pengetahuan dan teknologi dimana manfaatnya langsung dirasakan oleh masyarakat. 10) Bagi tim dosen pelaksana merupakan bentuk nyata karya praktek yang berkolaborasi dengan mahasiswa dan masyarakat dalam memecahkan masalah pemberdayaan ekonomi masyarakat setempat dalam skala mikro secara mendasar, bertahap dan terukur. Dalam kegiatan ini pemberdayaan diartikan sebagai upaya untuk memberikan daya (empowerment) atau penguatan (strengthening) kepada masyarakat (Mas'oed : 1993). Sedangkan keberdayaan masyarakat juga dipandang sebagai kemampuan individu yang bersenyawa dengan masyarakat dalam membangun keberdayaan masyarakat yang bersangkutan (Sumodiningrat : 1997).

Disamping itu pula tim pelaksana menyelenggarakan kegiatan inti dalam bentuk bimbingan penguatan tata kelola keuangan, bahan baku, produksi dan peningkatan kualitas. Untuk itu juga dibutuhkan evaluasi. Pendekatan sistem dalam evaluasi programprogram pemberdayaan yakni suatu kegiatan evaluasi yang tidak hanya dilaukan terhadap proses kegiatan, tetappi diarahkan pada kegiatan evaluasi secara keseluruhan unsur dari pemberdayaan itu sendiri (Soumelis : 1983). Evaluasi sebagai proses menggambarkan, memperoleh dan menyediakan informasi yang berguna utuk menilai alternative keputusan (Tayibnapis: 2008). Selanjutnya untuk menghasilkan kegiatan bimtek yang efektif maka materi bimbingan teknis disusun berdasarkan kebutuhan kelompok sasaran dengan rincian materi sebagai berikut:

1) Materi Pertama: Tata kelola keuangan usaha mikro kecil dan menengah. Materi ini dimulai dari pengungkapan berbagai potensi ril yang dimiliki desa salah satunya potensi produk karawo yang banyak terdapat di wilayah ini. Materi dilanjutkan dengan tata kelola keuangan untuk pembiayaan ragam produk karawo. Disamping itu pula diuraikan secara rinci berbagai masalah yang dihadapi oleh masyarakat dan kelompok masyarakat pengrajin sulaman kain karawo, baik masalah penyusunan rencana pembiayaan, akses permodalan, pengalokasian biaya dan pengukuran efektifitas serta efisiensi penggunaan dana. Dalam materi ini juga menyajikan berbagai contoh kasus keberhasilan dan kegagalan sektor usaha mikro kecil menengah (UMKM). Dengan menyajikan contoh kasus tersebut kelompok sasaran dapat mengambil manfaat praktis dalam tata kelola keuangan. Evaluasi materi ini dilakukan untuk mengukur hasil kemampuan kelompok sasaran dalam memahami dan mempraktekkannya pada kegiatan usaha kelompok, melakukan koreksi dan tindakan perbaikan lebih lanjut. Pada materi ini target yang dicapai adalah $80 \%$ kelompok sasaran mampu memahami dan mempraktekkan tata kelola keuangan yang efektif dan efisien dalam rangka penguatan manajemen. Adapun sisanya sejumlah $20 \%$ masih membutuhkan tindaklanjut koreksi perbaikan dan pendampingan lanjutan oleh tim pelaksana PPPUD.

2) Materi Kedua: Penetapan standar dan pemenuhan bahan baku serta bahan pendukung. Materi ini menegaskan pentingnya penetapan standarisasi bahan baku dalam upaya menjamin qualitas ragam produksi sulaman kain karawo. Disamping itu pula materi ini mengulas lebih rinci tentang pentingnya suplay bahan baku yang berkesinambungan untuk menjamin kontinuitas produksi. Materi penting lainnya mengenai penyusunan kontrak dengan mitra pemasok bahan baku untuk menjamin kualitas. Selain itu pula materi ini menegaskan tentang pentingnya kemampuan kelompok sasaran dalam menyusun kebutuhan bahan pendukung sebagai pelengkap kebutuhan produksi. Evaluasi pada materi ini dilakukan dengan cara mengamati dan mengukur kemampuan kelompok sasaran dalam mempraktekkan standarisasi produksi untuk masing-masing jenis produk karawo serta melakukan koreksi dan perbaikan lebih lanjut. Pemberian materi kedua telah ditetapkan target capaian $80 \%$ kelompok sasaran mampu memahami dan mempraktekkan standarisasi dan pemenuhan bahan baku sulaman kain karawo untuk menjamin kontinuitas produksi. Sisanya $20 \%$ kelompok sasaran masih membutuhkan pendampingan lanjutan dalam penerapannya.

3) Materi Ketiga: Standarisasi produksi jenis produksi karawo khas desa wisata Religius Bongo. Dalam materi ini ditegaskan tentang perlunya penyusunan rencana kegiatan secara ril, penyusunan tahapan rencana secara sistematis, pembagian tugas kelompok untuk penanganan standarisasi produksi, penetapan standarisasi untuk masing-masing jenis prosuksi karawo, pembahasan dan praktek peraturan dalam penerapan standar. Hal menarik yang terjadi dalam materi ini adalah adanya praktek oleh kelompok sasaran dalam penyusunan standarisasi produksi. Selain itu pula dilakukan kajian terhadap kasus keberhasilan dan kegagalan dalam penerapan standarisasi produksi. Materi ini mampu memberikan pengalam empirik bagi kelompok sasaran dalam standarisasi produksi ragam produk sulaman kain karawo. Evaluasi terhadap keberhasilan materi dilakukan melalui praktek standarisasi dalam kegiatan produksi, pengamatan langsung dilapangan, pengukuran tingkat keberhasilan, pemberian koreksi dan tindaklanjut 
perbaikan. Hasilnya menunjukkan $75 \%$ kelompok sasaran mampu mempraktekkan standarisasi produksi karawo. Sedangkan 25\% sisanya membutuhkan pengulangan dan pendampingan lanjutan dalam penerapannya.

4) Materi Keempat: Penetapan standarisasi qualitas ragam produk karawo sesuai kebutuhan pasar. Materi ini menegaskan akan pentingnya mengendepankan kualitas produksi karawo. Kualitas produksi pastilah akan berdampak pada tingkat permintaan produk oleh konsumen. Standarisasi produk karawo dapat dilakukan secara internal dan eksternal. Secara internal standarisasi ditetapkan oleh kelompok sasaran berdasarkan pengalaman yang diperoleh selama ini. Namun demikian disadari juga pentingnya mempertimbangkan ukuran kualitas dari perspektif konsumen. Oleh karena itu tim pelaksana PPPUD dan kelompok sasaran dalam materi ini juga melaksanakan praktek dalam bentuk survey untuk menjaring bagaimana ukuran kualitas produk karawo yang diinginkan oleh konsumen. Kombinasi antara faktor internal dan eksternal ini menjadi aspek yang memperkuat kualitas produk. Dampak yang diharapkan tentunya adalah jaminan terhadap kualitas dan peningkatan permintaan pasar. Evaluasi yang terhadap keberhasilan materi dilakukan melalui kemampuan dalam penerapan standar qualitas oleh kelompok sasaran. Evaluasi juga dilakukan melalui pengamatan langsung akan keterpakaian standar kualitas yang telah ditetapkan. Hasilnya menunjukkan bahwa 90\% kelompok sasaran mampu melaksanakan hasil bimbingan teknis sehingga memberikan dampak positif dalam tata kelola standarisasi ragam produksi karawo.

5) Materi Kelima: Aspek Manajemen Usaha. Materi ini menegaskan akan pentingnya manajemen usaha yang profesional dalam operasional bisnis. Hal penting lainnya dalam materi ini adalah tentang manajemen strategis. Manajemen strategis merupakan suatu rencana yang disusun dan dikelola dengan memperhitungkan berbagai sisi dengan tujuan agar pengaruh rencana memberikan dampak positif bagi organisasi dalam jangka panjang (Fahmi: 2015). Manajemen sebagai kunci kesuksesan bisnis dilakukan melalui praktek fungsi-fungsi manajemen yang meliputi: perencanaan, pengorganisasian, pelaksanaan, pemasaran dan evaluasi untuk keberlanjutan usaha. Disamping fungsi manajemen dibahas pula dalam materi ini menyangkut unsur-unsur manajemen yang meliputi: manusia (man), bahan (material), mesin (machine), uang (money) dan pasar (market). Kombinasi antara fungsi manajemen dan unsur manajemen menghasilkan efektifitas dan efisiensi manajemen bisnis yang berkelanjutan. Hasilnya menunjukkan: kelompok masyarakat sebagai sasaran memperoleh pengetahuan baru tentang manajemen bisnis sulaman kain karawo sebagai produk unggulan khas desa Wisata Religius Bongo. Bekal ilmu manajemen ini tentunya sangat berharga karena kelompok masyarakat langsung dapat mempraktekkan fungsi dan unsur manajemen secara bersamaan yang didampingi oleh tim pelaksana PPPUD tahun 2018.

6) Materi Keenam: Teori dan Praktek Penyusunan Studi kasus studi kelayakan bisnis. Pada materi ini anggota kelompok sasaran memperoleh pengetahuan dan pengalaman bagaimana menyusun program kerja yang realistis berdasarkan kondisi internal dan kondisi eksternal yang dihadapi oleh kelompok pengrajin pada masa sekarang dan perencanaan bisnis jangka panjang. Pengalaman tersebut meyakinkan anggota kelompok tentang prospek bisnis yang menjanjikan dan pasti untuk produk sulaman kain karawo yang direncanakan secara realistis, terencana dan sistematis. Dalam materi ini juga dipraktekkan tentang penyusunan rencana bisnis secara periode bulanan dan tahunan. Praktek juga difokuskan pada penyusunan tahapan-tahapan dalam mencapai rencana secara periodik. Kegiatan lainnya adalah simulasi bagaimana menangani permasalahan yang muncul baik secara internal maupun eksternal dan bagaimana pula menghadapi lingkungan bisnis eksternal yang berubah dengan sangat cepat. Hasilnya menunjukkan: Terjadi peningkatan kemampuan kapasitas kelompok pengrajin sulaman kain karawo dalam hal penyusunan rencana bisnis bulanan dan tahunan.

7) Materi Ketujuh: Praktek Inovasi Produk sulaman kain karawo. Praktek untuk inovasi produk dilakukan oleh praktisi, dalam hal ini salah satu mitra yang memiliki pengetahuan dan pengalaman luas tentang produksi sulaman kain karawo sesuai dengan standarisasi pasar. Semua peserta mengikuti dengan baik dan mempraktekkan inovasi tersebut untuk menghasilkan produkproduk terbaru sulaman kain karawo. Inovasi dilakukan dalam bentuk brand karawo sebagai produk unggulan khas desa wisata religius Bongo.

Berdasarkan hasil implementasi kegiatan pada khalayak sasaran maka diperoleh hasil sebagai berikut : 1) terdapat peningkatan pemahaman terhadap teori dan kemampuan dalam praktek tata kelola keuangan oleh kelompok sasaran. 2) meningkatnya kemampuan dalam pemenuhan bahan baku berdasarkan kebutuhan produksi. 3) terstandarisasinya proses produksi ragam produk karawo. 4) terpenuhinya kebutuhan ragam produk kain karawo sesuai dengan kebutuhan pasar. Secara umum rangkaian kegiatan pengabdian masyarakat telah memberikan pengalaman empirik dan manfaat baik bagi kelompok masyarakat sebagai sasaran, tim dosen pelaksana, perguruan tinggi dan pemerintah setempat. Hasil kegiatan bimbingan teknis penguatan kapasitas manajemen tata kelola keuangan, 
bahan baku, produksi dan produk bagi kelompok sasaran di Desa wisata religius Bongo telah memberikan pengalaman dan penguatan terhadap anggota kelompok pengrajin akan besarnya potensi bisnis sulaman kain karawo. Disamping itu pula bimbingan teknis memberikan bekal pengetahuan manajemen pengolahan usaha beserta implementasinya pada kegiatan usaha.

\section{KESIMPULAN}

Melalui program PPPUD di Desa wisata religius Bongo telah banyak memberikan pengetahuan dan pengalaman empirik bagi tim dosen pelaksana, pemerintah dan utamaya bagi kelompok sasaran. Berbagai manfaat tersebut setidaknya dapat diuraikan sebagai berikut:

1) Terwujudnya sinergi antara kelompok pengrajin dengan konsumen produk sulaman kain karawo sebagai kelompok sasaran dan masyarakat sekitarnya. Pemerintah setempat telah terbantu dalam hal meningkatkan pemberdayaan masyarakat kelompok pengrajin karawo bersama masyarakat sekitarnya.

2) Kegiatan ini sebagai kontribusi nyata dari perguruan tinggi dan tim dosen pelaksana dalam hal implementasi keilmuan untuk menjawab masalah mendasar yang dihadapi oleh kelompok sasaran di desa wisata religius Bongo.

Berdasarkan implementasi dan hasil akhir kegiatan maka tim pelaksana mengusulkan beberapa aspek sebagai berikut:

1) Program PPPUD harus tetap diadakan dengan pada masa yang akan datang karena telah terbukti berkontribusi nyata bagi masyarakat, pemerintah desa, dosen serta perguruan tinggi.

2) Program PPPUD perlu diperluas di berbagai wilayah terpencil untuk mengangkat berbagai potensi desa yang masih terpendam sebagai bentuk komitmen perguruan tinggi dalam program pengabdian kepada masyarakat.

3) Disarankan setelah selesainya kegiatan PPPUD dapat dikembangkan lagi melalui Program Pengembangan Program Eksport (PPPE) untuk terus menguatkan potensi sulaman kain karawo sebagai produk unggulan khas yang berasal dari desa wisata religius Bongo.

\section{UCAPAN TERIMAKASIH}

Setelah melalui berbagai tahapan proses kegiatan PPPUD Tahun 2018 maka hasil kegiatan ini telah memberikan manfaat bagi kelompok masyarakat dan kelompok ibu-ibu sebagai sasaran. Disamping itu pula manfaat bagi pemerintah Desa, dosen dan perguruan tinggi. Oleh karena itu pada kesempatan ini kami menyampaikan ucapan terimakasih disampaikan kepada 1) Direktorat jenderal pengabdian masyarakat Kementerian Ristek dan Dikti Republik Indonesia, 2) Pimpinan dan seluruh staf Lembaga Penelitian dan Pengabdian masyarakat Universitas Negeri Gorontalo, 3) Pemerintah Kabupaten Gorontalo, Kecamatan Batudaa Pantai dan pemerintah desa wisata religius
Bongo, 4) Kelompok Ibu-ibu kelompok ibu-ibu pengrajin sulaman kain karawo, 5) Tim pelaksana dan mahasiswa peserta PPPUD Tahun 2018. Semoga hasil kegiatan pengadian ini mampu memberikan manfaat jangka panjang bagi kelompok masyarakat sebagai sasaran dan anggota pengrajin, mitra usaha dan masyarakat sekitarnya.

\section{DAFTAR PUSTAKA}

Fahmi, Irfan, 2015, Manajemen Strategis, Teori dan Aplikasi, Penerbit Alfabeta, Bandung

Mas'oed, 1993, Ekonomi Politik Pembangunan dan pemberdayaan masyarakat dalam prospektif, Vol. 5 No. 2

Soumelis, 1983, Project Evaluation Methodologies and Techniques, Paris UNESCO

Tayibnapis, 2008, Evaluasi Program dan Instrumen Evaluasi untuk Program Pendidikan dan Penelitian, Jakarta Rineka Cipta

Sumodiningrat, G, 1997, Pembangunan daerah dan pemberdayaan masyarakat, Edisi Kedua, Jakarta, Bina Rena Pariwara 


\section{DOKUMENTASI KEGIATAN}
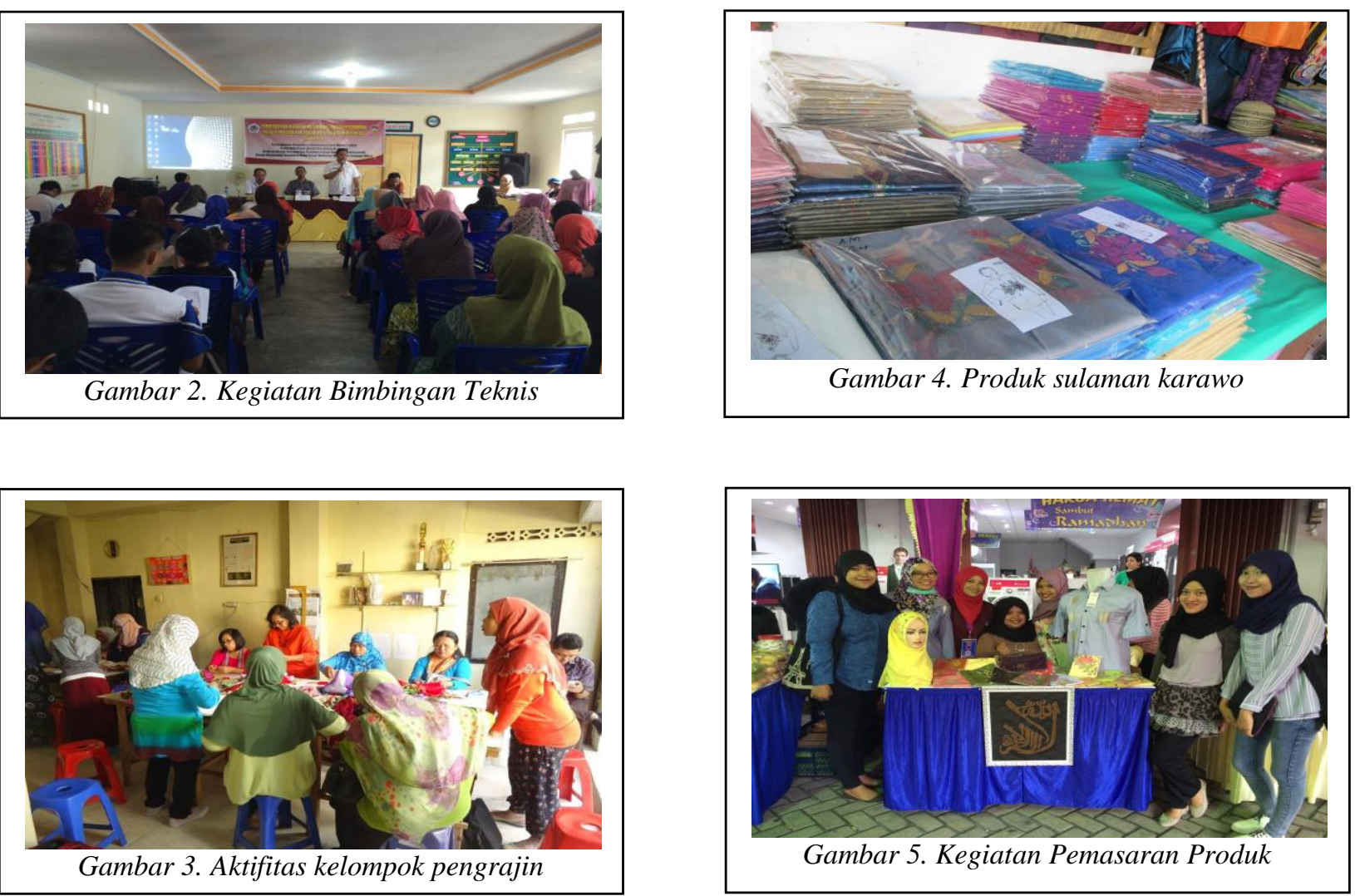